\title{
Teaching NeuroImages: Pericallosal curvilinear lipoma
}

Yao Fu, MD, PhD, Xiangyang Fang, MD, PhD, * Yanxin Li, MS, * and Xingli Zhao, MS

Neurology ${ }^{\circledR}$ 2019;93:e212-e213. doi:10.1212/WNL.0000000000007762

Correspondence

Dr. Zhao

zhao_xing_li@163.com

Figure Cranial MRI

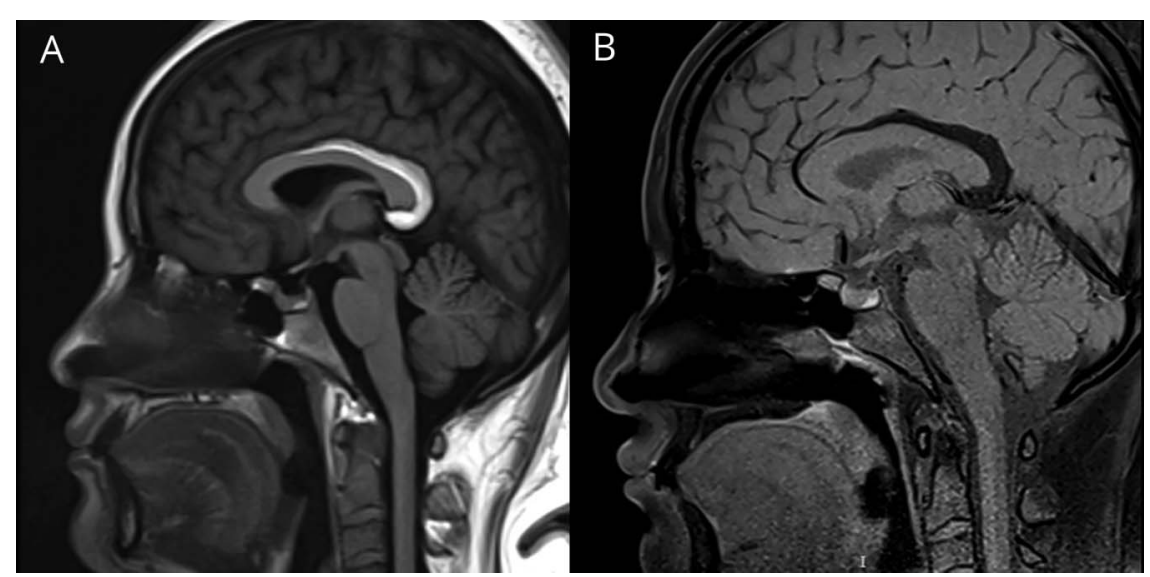

Sagittal T1-weighted MRI demonstrates an interhemispheric slender hyperintense mass over the corpus callosum (A), with signal attenuation on fat suppression sequence (B).
A 27-year-old woman presented to the neurosurgery department with a history of an incidental finding of an intracranial lesion. Neurologic examination was unremarkable. Cranial MRI revealed an interhemispheric lipoma over the corpus callosum (figure). A diagnosis of pericallosal curvilinear lipoma was made. Intracranial lipoma is a rare congenital malformation. ${ }^{1}$ Pericallosal region is the most common location of intracranial lipomas. Pericallosal lipoma can be divided into 2 morphologic subtypes: tubulonodular and curvilinear. ${ }^{2}$ The latter is mostly asymptomatic, occasionally presenting with seizures and headache, and has a low incidence of other accompanying anomalies. In this patient, surgical resection was not necessary, and regular follow-up was recommended.

\section{Study funding}

No targeted funding reported.

\section{Disclosure}

The authors report no disclosures relevant to the manuscript. Go to Neurology.org/N for full disclosures.

\section{References}

1. Rajan DS, Popescu A. Corpus callosum lipoma. Neurology 2012;78:1366.

2. Yildiz H, Hakyemez B, Koroglu M, et al. Intracranial lipomas: importance of localization. Neuroradiology 2006; 48:1-7.

\section{MORE ONLINE}

\section{$\rightarrow$ Teaching slides}

links.lww.com/WNL/

A917

*These authors contributed equally to this work.

From the Department of Neurosurgery, China-Japan Union Hospital of Jilin University, Changchun, Jilin Province, China.

Go to Neurology.org/N for full disclosures. 
Appendix Authors

\begin{tabular}{|c|c|c|c|}
\hline Name & Location & Role & Contribution \\
\hline $\begin{array}{l}\text { Yao Fu, MD, } \\
\text { PhD }\end{array}$ & $\begin{array}{l}\text { Jilin University, } \\
\text { Changchun, } \\
\text { China }\end{array}$ & Author & $\begin{array}{l}\text { Designed and conceptualized } \\
\text { study, analyzed the data, } \\
\text { drafted the manuscript for } \\
\text { intellectual content }\end{array}$ \\
\hline $\begin{array}{l}\text { Xiangyang } \\
\text { Fang, MD, } \\
\text { PhD }\end{array}$ & $\begin{array}{l}\text { Jilin University, } \\
\text { Changchun, } \\
\text { China }\end{array}$ & Author & $\begin{array}{l}\text { Drafting and revision of the } \\
\text { manuscript }\end{array}$ \\
\hline $\begin{array}{l}\text { Yanxin Li, } \\
\text { MS }\end{array}$ & $\begin{array}{l}\text { Jilin University, } \\
\text { Changchun, } \\
\text { China }\end{array}$ & Author & $\begin{array}{l}\text { Drafting and revision of the } \\
\text { manuscript }\end{array}$ \\
\hline $\begin{array}{l}\text { Xingli } \\
\text { Zhao, MS }\end{array}$ & $\begin{array}{l}\text { Jilin University, } \\
\text { Changchun, } \\
\text { China }\end{array}$ & Author & $\begin{array}{l}\text { Designed and conceptualized } \\
\text { study, analyzed the data, } \\
\text { drafted the manuscript for } \\
\text { intellectual content }\end{array}$ \\
\hline
\end{tabular}




\title{
Neurology
}

\author{
Teaching NeuroImages: Pericallosal curvilinear lipoma \\ Yao Fu, Xiangyang Fang, Yanxin Li, et al. \\ Neurology 2019;93; $212-\mathrm{e} 213$ \\ DOI 10.1212/WNL.0000000000007762
}

This information is current as of July 8, 2019

\section{Updated Information \& Services}

References

Subspecialty Collections

Permissions \& Licensing

Reprints including high resolution figures, can be found at: http://n.neurology.org/content/93/2/e212.full

This article cites 2 articles, 1 of which you can access for free at: http://n.neurology.org/content/93/2/e212.full\#ref-list-1

This article, along with others on similar topics, appears in the following collection(s):

All Clinical Neurology

http://n.neurology.org/cgi/collection/all_clinical_neurology MRI

http://n.neurology.org/cgi/collection/mri

Information about reproducing this article in parts (figures,tables) or in its entirety can be found online at:

http://www.neurology.org/about/about_the_journal\#permissions

Information about ordering reprints can be found online:

http://n.neurology.org/subscribers/advertise

Neurology ${ }^{\circledR}$ is the official journal of the American Academy of Neurology. Published continuously since 1951, it is now a weekly with 48 issues per year. Copyright (O 2019 American Academy of Neurology. All rights reserved. Print ISSN: 0028-3878. Online ISSN: 1526-632X.

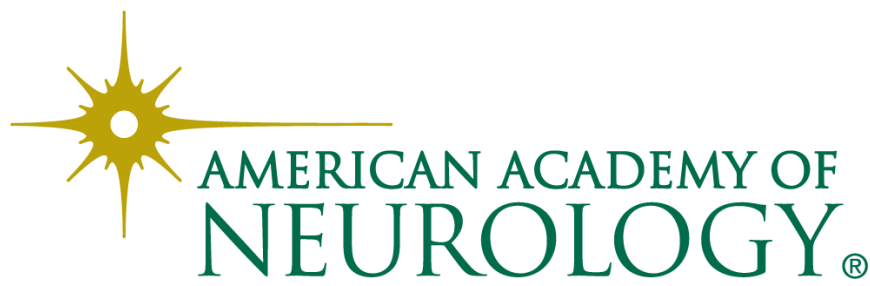

